Bull. Egypt. Soc. Physiol. Sci. Vol. (42) Issue (1), 39-51

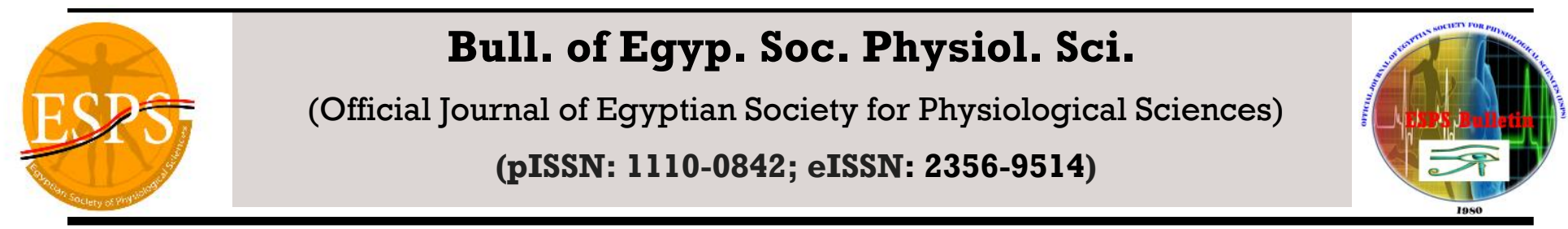

\title{
Study the Role of Vitamin D on Some Brain Degenerative Disorders in Male Albino Rats
}

\author{
Fatma Fayed, Sahar Elsawy, Mohamed Shebl, Haidy Khattab \\ Medical Physiology Department, Faculty of Medicine, Tanta University
}

Submit Date: 21 May 2021

Revise Date: 29 June 2021

Accept Date : 30 August 2021

\section{Keywords}

Vitamin D,

Aluminum Chloride

ACHE

MDA

GPX

\section{Abstract}

Background: Vitamin D, a steroid hormone that plays an important role in bone and calcium metabolism, now is known it has different beneficial functions and actions on various tissues and cell types. There are evidences that vitamin D implies some functions in the central nervous system as a neurosteroid hormone. Aim: Study the role of vitamin $\mathrm{D}$ on aluminum chloride $(\mathrm{AlCl} 3)$ induced brain degeneration in male albino rats. Materials and Methods: This study was carried out on 50 adult male Wistar albino rats. The rats were divided into three groups: Group I (Control group) received normal saline followed by corn oil. Group II ( $\mathrm{AlCl} 3$ treated group) received $\mathrm{AlCl} 3$ followed by corn oil. Group III (VD3 treated group): subdivided into Group IIIa received VD3 followed by both $\mathrm{AlCl} 3$ and VD3. Group IIIb: received $\mathrm{AlCl} 3$ followed by VD3. Behavioral tests were done. Brain tissue acetylcholinesterase activity, malondialdehyde and glutathione peroxidase were assessed. Results: The results revealed that in $\mathrm{AlCl} 3$ treated group, there was a significant decrease in acetylcholinesterase level and glutathione peroxidase and a significant increase in malondialdehyde compared to the control group and significant increase in acetylcholinesterase level and glutathione peroxidase, and a significant decrease in malondialdehyde in VD3 treated group compared to $\mathrm{AlCl} 3$ treated group; there was also improvement in behavioral parameters inVD3 treated group compared to $\mathrm{AlCl} 3$ treated group. Conclusion: We concluded that either the protective or the therapeutic effect of vitamin D produced significant improvement in motor impairment, learning, and memory. 


\section{INTRODUCTION}

Vitamin D, a steroid hormone that plays an important role in bone and calcium metabolism, it has different beneficial functions and actions on various tissues and cell types.(1)

Researches suggest that vitamin D plays an essential role in preventing and/or decreasing the risk of a variety of neurodegenerative disorders. The risk of neurodegenerative pathologies may be increased by Vitamin D deficiency. (2)

$1 \alpha, 25$-dihydroxy-vitamin $\mathrm{D}$ or simply calcitriol, is the active form of vitamin D (VD3) plays a pivotal role to maintain the normal neuronal function, such as immunomodulation and detoxification processes.(3)

Anti-oxidants activity is one of the important effects of VD3; it improves brain enzyme activity by reducing lipid peroxidation. VD3 deficiency will result in dysregulation in reactive oxygen species (ROS) and $\mathrm{Ca} 2+$ signaling pathways. In some neurodegenerative pathologies as Alzheimer's disease, it might initiate beta-amyloid formation, which progresses to neuronal death and dementia .(4)

The proposed mechanism of action of VD3 is explained by its ability to bind to the activated VD3 receptor/retinoic $\mathrm{X}$ receptor heterodimeric complex to specific DNA sequences that control gene expression.(5) VD3 probably affects genes involved in glutamatergic and GABA-ergic neurotransmissions, calcium regulation, as well as neurotrophic factors and genes involved in neuroprotection. (6)

VD3 is necessary for brain function, like, neurotransmission, synapse formation, synaptic plasticity, and dendritic arborization and its deficiency may have a negative effect on these critical processes. (7) Furthermore, VD3 deficiency acts as a risk factor for Parkinson's disease development. (8)

There are many environmental toxicants that have the capacity to impair the brain. Aluminum (Al) is the most abundant metal present on the earth's crust. It is extensively used in daily life and was found in drinking water probably due to water purification procedures, the new 20th century industrial products containing $\mathrm{Al}$ salts. Aluminum's slow progressive uptake into the brain over a long prodromal phase. (9)

We designed the current study to assess the effect of vit $\mathrm{D}$ on aluminum chloride induced brain damage in male albino rats.

There is controversy about the relation of vitamin D status and cognitive function and whether its deficiency is the cause of the disease progression.

\section{Material and Methods:}

\section{Chemicals and Reagents:}

\section{Vitamin D:}

Vitamin D (Deverol S®, colecalciferol, VD3) was purchased from Mephis company as $2 \mathrm{ml}$ ampoule containing $5 \mathrm{mg}$ equivalent to $200,000 \mathrm{IU}$ ( $1 \mathrm{IU}$ is the biological equivalent of $0.025 \mu \mathrm{g}$ ), each ampoule was diluted by corn oil from Sigma Aldrich to give a concentration of $0.125 \mu \mathrm{g} / \mathrm{ml}$. (11)

\section{Aluminum chloride:}

$\mathrm{AlCl}_{3}\left(1 \mathrm{AlCl}_{3}: 6 \mathrm{H} 2 \mathrm{O}\right)$ was purchased from Sigma -Aldrich as powder $1 \mathrm{Kg}$ is prepared by dissolving $2.414 \mathrm{gm}$ of salt per litre of distilled water.

\section{Experimental Animals:}

This study was carried out on 50 adult male Wistar albino rats (weighing 150 - 200g). All rats were 
housed in the animal house at the Faculty of Medicine Tanta University in cages measured $70 \times 70 \times 60 \mathrm{~cm} 5$ animals per cage under a standard animal laboratory room temperature with free access to water and food. All procedures were subjected to the ethical committee of Tanta University approval number 32902/2/19. The duration of the research started from February 2019 till February 2020.

\section{Experimental design:}

The rats were divided into three groups as the following:

Group I (Control group) (10 rats): They received intraperitoneal (IP) injection of $1 \mathrm{ml}$ normal saline once daily for two weeks followed by intramuscular (IM) injection of $0.5 \mathrm{ml} / \mathrm{kg}$ corn oil once daily for two weeks. ${ }^{(12)}$

Group II (AICl3 treated group) (20 rats): These animals received IP injection of $(\mathrm{AlCl} 3)$ at a dose of $7 \mathrm{mg} / \mathrm{kg}$ body weight once daily for two consecutive weeks followed by IM injection of 0.5 $\mathrm{ml} / \mathrm{kg}$ corn oil for two weeks. ${ }^{(13)}$
Group III (VD3 treated group) (20 rats): The animals of this group were subdivided into:

Group III a (10 rats): These animals were received IM injection of VD3 at a dose of $1 \mu \mathrm{g} / \mathrm{kg}$ once daily for 7 days, followed by injection of both $\mathrm{AlCl}_{3}$ at a dose of $7 \mathrm{mg} / \mathrm{kg}$ body weight once daily and the same dose of VD3 for two weeks then rats have received IP injection of $1 \mathrm{ml}$ normal saline once daily for one week. ${ }^{(3)}$

Group III b (10 rats): The animals of this group were received IP injection of $\mathrm{AlCl}_{3}$ at a dose of 7 $\mathrm{mg} / \mathrm{kg}$ body weight once daily for two consecutive weeks followed by IM injection of VD3 at a dose of $1 \mu \mathrm{g} / \mathrm{kg}$ once daily for two weeks. ${ }^{(4)}$

At the end of the experimental period ten rats died from aluminum chloride treated group ,the final numbers were, group $\mathrm{I}=10$, group $\mathrm{II}=10$, group $\mathrm{IIIa}=10$ and group $\mathrm{IIIb}=10$

We gave each substance throughout the day according to table (1).

All the animals from all groups were subjected for:

Table (1) Time table of given each substance through out the day

\begin{tabular}{|l|c|c|c|c|}
\hline Substance injected & Group I & Group II & Group IIIa & Group IIIb \\
\hline $\begin{array}{l}\text { Normal saline in the first two } \\
\text { weeks }\end{array}$ & 9 A.M & & & \\
\hline Corn oil in the last two weeks & 9 A.M & & & \\
\hline AlCl3 in the first two weeks & & 9 A.M & & \\
\hline Corn oil in the last two weeks & & 9 A.M & & \\
\hline VD3 for 7 days & & & 9 A.M & \\
\hline $\begin{array}{l}\text { AlCl3 in } 2^{\text {nd }} \& 3^{\text {rd }} \text { weeks } \\
\& V D 3 \text { in } 2^{\text {nd }} \& 3^{\text {rd }} \text { weeks }\end{array}$ & & 8 A.M & \\
\hline normal saline for the $4^{\text {th }}$ week & & & 9.M & \\
\hline AlCl3 for 1 st two weeks & & & & 9.M \\
\hline VD3 for last two weeks & & & & 9 A.M \\
\hline
\end{tabular}

\section{Behavioral tests:}

\section{Locomotor Activity Test (Open field}

test): This test was performed in order to evaluate the exploratory behavior, as an index of spontaneous motor activity and was done according to protocol described by Broadhurst,(14). 
Locomotor activity of the rat was measured using the open field test. During this test, animals were allowed to freely explore the apparatus for $15 \mathrm{~min}$. Each rat was placed in the center of the open field and the distance traveled every $5 \mathrm{~min}$ was recorded for $15 \mathrm{~min}$. After the behavioral evaluation of each rat, the apparatus was cleaned with $5 \%$ ethanol solution.

2. Forced swimming test : This test was centered on animal's response to the threat of drowning, whose result had been interpreted as measuring susceptibility to negative mood and was done according to procedure described by Castagné et al., (15).

The animals were placed individually into a cylinder (40 cm height and $23 \mathrm{~cm}$ diameter), containing water up to $25 \mathrm{~cm}$ below the top. The immobility time was monitored for 5 ( $\mathrm{min})$, after an initial $1 \mathrm{~min}$ adaptation period. The reduction of this immobility time is suggestive of an antidepressive-like action.

3. T-maze test: Elevated T-maze (ETM) In this study, the ETM was used to assess learning and memory features in rats.The experimental protocol was based on the report of Conde et al., (16).

In the training session, which was performed only on one day,rats were re-exposed to the ETM as many times as needed to remain in the enclosed arm for $300 \mathrm{~s}$ (avoidance criterion). The number of trials to reach the avoidance criterion was used to assess learning. The time in which the animal remained in the enclosed arm was recorded for each trial (avoidance latency).

Twenty-four hours after training (test session), rats were re-exposed to the enclosed arm during two subsequent trials (i.e., test and retest). The time that the animal remained in the enclosed arm was recorded and used to assess memory retrieval. Experiments were performed in a dim light and quiet room with an observer inside the room (3 $\mathrm{m} \times 3 \mathrm{~m}$ ) seated at least $2 \mathrm{~m}$ from the open arms of the apparatus.

All experiments were performed between 13:00 and 17:00. The apparatus was cleaned with 5\% ethanol solution between subjects.

\section{Tissue sample preparation:}

After anesthetization by IP injection of pentobarbital at a dose of $800 \mathrm{mg} / \mathrm{kg}$ (17), animals were sacrificed. The brains were immediately removed, placed in ice-cold isotonic saline and the cerebrum was dissected then stored at $-80^{\circ} \mathrm{C}$. Later the brain tissue was taken and minced into small pieces, which were later used for the estimation of the following parameters:

- Acetylcholinesterase (AChE) activity according to the method described by Magnotti et al., (18).

- Glutathione Peroxidase (GPX) according to the method described by Rotruck et al., (19).

- Malondialdehyde (MDA), according to the method described by Ohkawa et al., (20).

The sacrificed animals were packed in a special package according to safety precautions and infection control measures and were sent with hospital biohazard.

\section{Statistical analysis:}

The data were analyzed using Statistical Program for Social Science (SPSS) version 22.0. Quantitative data were expressed as mean \pm standard deviation (SD). 
ANOVA and Tukey tests were used to compare the groups. $\mathrm{P}$ value less than 0.05 indicates significance.

\section{Results:}

\section{I-Animal survival}

Ten rats died from aluminum chloride treated group.

\section{II-Behavioral tests:}

1-Open field test (distance/time) $(\mathrm{mm} / 15$ minute) ( table 2):

Locomotion (distance travelled every 5 min for 15 min) in animals of group II showed a significant decrease $(\mathrm{P} \leq 0.05)$ when compared to that of group I; however, it showed a significant increase $(\mathrm{P} \leq 0.05)$ in group IIIa and group IIIb when compared to that of group II moreover, they showed a significant increase $(\mathrm{P} \leq 0.05)$ in group IIIa when compared to that of group IIIb.

2-Forced Swimming test (immobility time) (seconds/5minute) ( table 2):

Immobility time in animals of group II showed a significant increase in $(\mathrm{P} \leq 0.05)$ when compared to that of group I; however, it showed a significant decrease $(\mathrm{P} \leq 0.05)$ in group IIIa and group IIIb when compared to that of group II, there also significant decrease $(\mathrm{P} \leq 0.05)$ in group IIIa when compared to that of group IIIb.

\section{3-T-maze test: Elevated T-maze (ETM) task}

\section{A-Training session: number of trials ( table 2):}

The number of trials in animals of group II showed a significant increase $(\mathrm{P} \leq 0.05)$ when compared to that of group I; however, it showed a significant decrease $(\mathrm{P} \leq 0.05)$ in group IIIa and group IIIb when compared to that of group II; moreover, they showed a significant decrease $(\mathrm{P} \leq 0.05)$ in group IIIa when compared to that of group IIIlb.

\section{B-Retest Session ( table 2):}

The time animals remain in enclosed arm in retest session in animals of group II showed a significant decrease $(\mathrm{P} \leq 0.05)$ when compared to that of group I; however, it showed a significant increase $(\mathrm{P} \leq 0.05)$ in group IIIa and group IIIb when compared to that of group II; moreover, they showed a significant increase $(\mathrm{P} \leq 0.05)$ in group IIIa when compared to that of group IIIlb.

\section{III-Tissue AChE, glutathione peroxidase and} Malondialdehyde activity:

1- Tissue AChE activity and tissue glutathione peroxidase activity in all studied groups( table (3):

It showed a significant decrease $(\mathrm{P} \leq 0.05)$ in tissue Ach $\mathrm{E}$ activity and tissue glutathione peroxidase activity in animals of group II when compared to that of group I; however, it showed a significant increase $(\mathrm{P} \leq 0.05)$ in group IIIa and group IIIb when compared to that of group II; moreover, they showed a significant increase $(\mathrm{P} \leq 0.05)$ in group IIIa when compared to that of group IIIlb.

2-Tissue Malondialdehyde (MDA) activity in all studied groups Table (3):

It showed a significant increase $(\mathrm{P} \leq 0.05)$ in tissue MDA activity in animals of group II when compared to that of group I; however, it showed a significant decrease $(\mathrm{P} \leq 0.05)$ in group IIIa and group IIIb when compared to that of group II; moreover, they showed a significant decrease $(\mathrm{P} \leq 0.05)$ in group IIIa when compared to that of group IIIb. 
Table (2): Open field test (distance/time) \& forced Swimming test (immobility time) and T-maze test in all studied groups :

\begin{tabular}{|l|c|c|c|c|}
\hline \multirow{2}{*}{ Groups } & $\begin{array}{c}\text { Group I(10rats) } \\
\text { (control) } \\
\text { mean + SD }\end{array}$ & $\begin{array}{c}\text { Group II(10rats) } \\
\text { (AlCl3tt) } \\
\text { mean } \pm \text { SD }\end{array}$ & $\begin{array}{c}\text { Group III (Vit D ttt) } \\
\text { IIIa(10rats) } \\
\text { mean } \pm \text { SD }\end{array}$ & $\begin{array}{c}\text { IIIb (10rats) } \\
\text { mean } \pm \text { SD }\end{array}$ \\
\hline $\begin{array}{l}\text { Open field test } \\
\text { (distance/time) } \\
\text { (mm/15 minute) }\end{array}$ & $58.6 \pm 2.22$ & $43 \pm 2.00^{*}$ & $57.5 \pm 2.41^{\# \Delta}$ & $52.4 \pm 2.06^{\#}$ \\
\hline $\begin{array}{l}\text { Forced Swimming } \\
\text { test (immobility time) } \\
\text { (seconds/5minute }\end{array}$ & $44.7 \pm 3.05$ & $85.5 \pm 3.68^{*}$ & $46.7 \pm 2.58^{\# \Delta}$ & $56.4 \pm 2.67^{\#}$ \\
\hline $\begin{array}{l}\text { T-maze test: } \\
\text { numbers of trials }\end{array}$ & $7.2 \pm 1.619$ & $14.3 \pm 1.160^{*}$ & $8.2 \pm 1.169^{\# \Delta}$ & $11.5 \pm 0.527^{\#}$ \\
\hline $\begin{array}{l}\text { T-maze: Re test } \\
\text { Session (seconds) }\end{array}$ & $175.5 \pm 3.02$ & $145.7 \pm 3.59^{*}$ & $173.5 \pm 2.72^{\# \Delta}$ & $164.5 \pm 3.03^{\#}$ \\
\hline
\end{tabular}

$* \# \Delta$ denotes statistical significance $(\mathrm{P} \leq 0.05)$

* versus Group I

\# versus Group II

$\Delta$ Group IIIa vs Group IIIb

ttt treated

Table (3): Tissue AChE activity \& Glutathione Peroxidase (GPX) and Malondialdehyde in all studied groups :

\begin{tabular}{|l|c|c|c|c|}
\hline \multicolumn{1}{|c|}{ Parameters } & $\begin{array}{c}\text { Group I (10 rats) } \\
\text { (control) } \\
\text { mean } \pm \text { SD }\end{array}$ & $\begin{array}{c}\text { Group II (10 rats) } \\
\text { (AlCl } \mathbf{~ t t )} \\
\text { mean } \pm \text { SD }\end{array}$ & $\begin{array}{c}\text { Group III (Vit D ttt) } \\
\text { mean } \pm \text { SD }\end{array}$ & $\begin{array}{c}\text { IIIb (10 rats) } \\
\text { mean } \pm \text { SD }\end{array}$ \\
\hline $\begin{array}{l}\text { Tissue Ach E activity } \\
\text { (mU/ml/g) }\end{array}$ & $896.32 \pm 0.18$ & $893.55 \pm 0.37^{*}$ & $896.28 \pm 0.18^{\# \Delta}$ & $895.74 \pm 0.32^{\#}$ \\
\hline $\begin{array}{l}\text { Glutathione } \\
\text { Peroxidase (GPX) } \\
\text { nmol/min /mg of } \\
\text { protein }\end{array}$ & $1.32 \pm 0.17$ & $0.52 \pm 0.16^{*}$ & $1.29 \pm 0.16^{\# \Delta}$ & $0.87 \pm 0.05^{\#}$ \\
\hline $\begin{array}{l}\text { Malondialdehyde } \\
\text { (MDA) (nmol/g) }\end{array}$ & $6.38 \pm 0.19$ & $7.49 \pm 0.34^{*}$ & $6.42 \pm 0.18^{\# \Delta}$ & $6.72 \pm 0.17^{\#}$ \\
\hline
\end{tabular}

$* \# \Delta$ denotes statistical significance $(\mathrm{P} \leq 0.05)$

*versus Group I

\# versus Group II

$\Delta$ Group IIIa vs Group IIIb

$\mathrm{ttt}$ treated

\section{Discussion:}

Vitamin D hormone is essential for growth and differentiation in a variety of organs, including the brain. Numerous data suggest that vitamin D plays an important role in the brain through the induction of many CNS genes, neurotrophins release and activity of key neurotransmitter metabolism enzymes (21). Aluminum chloride is a well-known neurotoxicant reported to accelerate oxidative damage to biomolecules. (22)
Our aim is to study the prophylactic and therapeutic role of VD3 in aluminum chloride induced brain degeneration.

Our study confirmed that injection of $\mathrm{AlCl} 3$ in rats causes brain degeneration, evidenced by a decrease in tissue AChE level.

In agreement with our results, Taïr et al., (23) found that $\mathrm{AlCl} 3$ administration in rats produced a significant decrease in cerebrum AChE activity compared to control rats. 
The explanation of our results is that exposure of rats to $\mathrm{AlCl} 3$ caused accumulation of the neurotoxicant at different levels in the brain, affecting even serotoninergic neurotransmission.(20)

In disagreement with our results, $\mathrm{Al}$ exposure leads to an increase in $\mathrm{AChE}$ activity in the brain of rats. (21) This could be explained by the hypothesis of the biphasic effect of aluminum related to the metal exposure duration established by Gabriela et al. (24)

Treatment by Vit D showed a significant increase in tissue AChE level; our study also showed that Vit $\mathrm{D}$ has a protective effect against aluminum chloride toxicity as evidenced by a significant increase in AChE level in group IIIa compared with IIIb.

In agreement with our results, Medhat et al., (25) found that AChE showed a significant increase in VD3 treated group compared to Alzheimer group.

Zhang and Greenberg, (26) reported that the human AChE promoter contains many binding sites for osteogenic factors, including 1,25-(OH)2 VD3 and 17b-estradiol.

Our results regard behavioral tests showed a significant increase (immobility time in forced swimming test and a number of trials and a significant decrease in (locomotion in open field test and time animals remain in enclosed arm in test and retest session) in $\mathrm{AlCl} 3$ treated group compared to control group. Aluminum chloride was found to decrease the crossing scores according to the results obtained after performing in the open field apparatus.

Similar observations have also been reported by Colomina, et al., (27), who noticed a significant reduction in spontaneous locomotor activity after aluminum treatment of rats.

In disagreement with our results, Berihu et al., (28) showed that $\mathrm{Al}$ increased the activity scores of locomotor activity. The hyperactivity observed in these tests were considered to be the result of stress conditions.

An explanation of our findings may be that $\mathrm{Al}$ competes in the biological systems with cations, especially with magnesium. Also, aluminum binds to transferrin and to citrate in the plasma, and it can also influence the secondary transmission systems and availability of calcium (29).

Scientific data showed that Al interferes with the main neurotransmitters regarding their synthesis, storage, release, activation or inactivation of their receptors (30).

Observations and studies show that aluminum intoxication decreases by $40 \%$ the level of dopamine in the substsntia nigra and causes an imbalance of dopamine metabolites, suggesting alteration of its metabolism. (31)

Cordeiro et al., (30) showed that Al disturbs the $\mathrm{Ca} 2+/$ calmodulin signal-dependent of calcineurin that regulates the process of passing the system via the synaptic membrane.

In agreement with our results, Berihu, et al., (28) found that the result of the forced swimming test showed a significantly increased immobility time of aluminum-treated mice.

A study in which Al was administered intraperitoneally showed that the metal produces a decrease of density in dopamine D1 and D2 receptors from the cortex. (32)

Administration of $\mathrm{AlCl} 3$ to rats led to decreased levels of serotonin and its metabolite 5-hydroxyindoleacetic acid in the cortex; these changes are 
related to the inhibitory effect of aluminum on serotonin by cholinergic input loss .(33)

However, Berihu et al., (28) concluded that $\mathrm{AlCl} 3$ exposure has negative effects on the anxietyrelated behavior of rats, as indicated by the increased rate of anxiety in $\mathrm{Al}$ treated rats.

Explanation of these results may be due to a decline in learning ability induced by the deterioration of hippocampal function.(34)

Our results regard behavioral tests showed a significant increase in (locomotion in open field test and time animals remain in enclosed arm in test and retest session) and a significant decrease in( immobility time in forced swimming test and the number of trials) in VD3 treated group compared with group $\mathrm{AlCl} 3$ treated group and significant change in group IIIb compared with group IIIa.

The dopamine metabolism in the forebrain is affected by VD3 deficiency with a decreased conversion of 3, 4-dihydroxyphenylacetic acid (DOPAC) to homovanillic acid HVA. (35)

Eyles et al., (36) showed that the substantia nigra presents one of the highest brain concentrations of VDR, indicating the importance of this mediator in dopaminergic pathways.

The rate-limiting enzyme for dopamine synthesis Tyrosine hydroxylase (TH) might be directly modulated by VD3, as observed by immunohistochemistry staining. (37)

Cui et al., (38) demonstrated that VD3 partially restores $\mathrm{TH}$ protein and $\mathrm{TH}$-immunoreactive fibers. These effects also increased the glialderived neurotrophic factor (GDNF) protein, contributing to VD3 neuroprotective effects on dopaminergic neurons.
Orme et al., (39) demonstrated that VD3 increase in the number of dopaminergic neurons and upregulation of GDNF protein.

Mahar et al., (40) suggested that VD3 signaling could be regulated in the brain in response to stress, one of the major environmental factors associated with the occurrence of major depressive disorder episodes.

Latimer et al., (41) examined the effects of longterm dietary manipulation of serum VD3 and tested the hypothesis that cognitive decline with ageing can be slowed or prevented by higher VD3 levels; the results of the study provide evidence of a potential cause-and-effect relationship because raising VD3 levels prevented age-related cognitive decline.

Medhat et al., (24) confirm the effective role of VD3 in the improvement of the cognitive functions of brain treated rats.

The mechanisms by which the VD3 undergoes the behavioral aspects of the neurocognition, neuroprotection are through anti-oxidative, immunemodulation, (42) neuronal calcium regulation, enhanced nerve conduction and detoxification.(43) VD3 up-regulates gamma glutamyl transpeptidase (44), increasing anti-oxidant glutathione. Additionally, similar to the benefits of traditional anti-oxidant nutrients, VD3 inhibits inducible NO syntheses (45) that serves to protect the brain from free radicals-induced damage. VD3 has been also shown to attenuate the neurotoxicity of 6hydroxydopamine exposure in rats (41). These neuroprotective effects influence the cognitive function of the brain.

VDR and catalytic enzymes are co-localized in the areas of the brain involved in complex planning, processing, and formation of new memories. (47) 
VD3 up-regulates neurotrophin factors such as NT-3 (48). NT-3is found in the hippocampus, which is especially sensitive to age or pathologyrelated degeneration (49) and neocortex and protects nerve transmission and synaptic plasticity.

Our study revealed that $\mathrm{AlCl} 3$ affect oxidative stress evidenced by increased tissue MDA level and decrease in tissue Glutathione Peroxidase activity in $\mathrm{AlCl} 3$ treated group compared with the control group. In agreement with our results,

Similar results were mentioned by Nedzvetsky et al., (50). (who stated that Al-induced a significant increase in MDA concentration in the frontal cortex of rats.

Nearly similar findings were obtained by Manal et al., (51) they demonstrated that administration of $\mathrm{AlCl} 3$ induced elevation of LPO in the brain of $\mathrm{Al}-$ treated rats. This is evidenced by the increased production of MDA, a negative correlation between $\mathrm{Al}$ exposure and GPX activities.

In addition, Yang et al., (52) reported that intraperitoneal injection of $\mathrm{AlCl} 3$ could accelerate lipid peroxidation in rat's brain.

All of these records are in agreement with the fact that $\mathrm{Al}$ reduced the total anti-oxidant parameter levels, enhancing the imbalance between prooxidant and anti-oxidant potentials (53).

The possible mechanisms for the elevation of lipid peroxidation are the binding of $\mathrm{Al}$ to negatively charged brain phospholipids, which contain polyunsaturated fatty acids and are easily attacked by ROS such as $\mathrm{O}-2, \mathrm{H} 2 \mathrm{O} 2$, and $\mathrm{OH}$ - which leads to an increase in lipid peroxidation. Another mechanism may be the direct neurotoxic effect of $\mathrm{Al}$ or perhaps a disarrangement of the cell membrane caused by increased lipid peroxidation. (54)

In our study tissue, MDA level showed significant decrease and tissue Glutathione Peroxidase activity showed a significant increase in VD3 treated group compared to $\mathrm{AlCl} 3$ treated group but tissue MDA level still significant increase and tissue Glutathione Peroxidase activity still a significant decrease in group IIIb compared with group IIIa.

In agreement with our results, Lima et al., (55) found that VD3 treatments significantly decreased nitrite contents and lipoperoxidation as related to the non-treated 6-OHDA rats, indicating that VD3 presents an anti-oxidant action.

The VD3 treatment was shown to increase cell viability and decrease ROS production. (56)

Hajiluian et al., (57) found that VD3 improved hippocampus oxidative stress and inflammatory markers in high-fat diet HFD induced obese rats and improved cognitive performance, VD3 supplementation in HFD group also significantly increased GPx and reduced MDA concentrations Oxidative stress is known to induce apoptosis, which is a key component in neurodegenerative diseases (58). Therefore, anti-oxidants have an essential role in the brain (59).

\section{Recommendation:}

We recommend further studies on the therapeutic effect of vitamin $\mathrm{D}$ either by increasing the dose or the duration of the treatment.

\section{References:}

1- Christakos S, Dhawan P, Porta A, Mady LJ, Seth T: Vitamin D and intestinal calcium absorption. Mol Cell Endocrinol 347(1-2):2529, 2011 
2- Knekt P, Sääksjärvi K, Järvinen R, et al: Serum 25-hydroxyvitamin d concentration and risk of dementia. Epidemiology 25(6):799-804, 2014

3- Kubis AM, Piwowar A: The new insight on the regulatory role of the vitamin D3 in metabolic pathways characteristic for cancerogenesis and neurodegenerative diseases. Ageing Res Rev 24( $\mathrm{Pt} \quad$ B):126137,2015

4- Berridge MJ: Vitamin D cell signalling in health and disease:Biochem Biophys Res Commun 460(1):53-71,2015

5- Christakos S, Dhawan P, Verstuyf A, Verlinden L, Carmeliet G. Vitamin D: Metabolism, Molecular Mechanism of Action, and Pleiotropic Effects. Physiol Rev 96(1):365-408,2016

6- Groves NJ, McGrath JJ, Burne TH:Vitamin $\mathrm{D}$ as a neurosteroid affecting the developing and adult brain: Annu Rev Nutr 34:117-141, 2014

7- Groves NJ, Burne THJ:The impact of vitamin D deficiency on neurogenesis in the adult brain. Neural Regen Res. 2017;12(3):393-394. doi:10.4103/16735374.202936

8- James LE, Asuni AA: Parkinson's disease and the "sunshine" vitamin. $J$ Alzheimers Dis\&parkin, 3(2), 1-10, 2013

9- Walton JR:Chronic aluminum intake causes Alzheimer's disease: applying Sir Austin Bradford Hill's causality criteria. J Alzheimers Dis 40(4):765-838, 2014

10- Doets EL, van Wijngaarden JP, Szczecińska A, et al:Vitamin B12 intake and status and cognitive function in elderly people. Epidemiol Rev 35:2-21, 2013

11- Alfredo R, Veronica E: Experimental Surgical Models in The Laboratory Rat: CRC Press, Taylor \& Francis Group: P: 206, 2009

12- Heydari M, Ahmadizadeh M, Ahmadi Angali K : Ameliorative effect of vitamin E on trichloroethylene-induced nephrotoxicity in rats. J Nephropathol.;6(3):168-173,2017.

13- Wu Z, Du Y, Xue H, Wu Y, Zhou B:Aluminum induces neurodegeneration and its toxicity arises from increased iron accumulation and reactive oxygen species (ROS) production. Neurobiol Aging 33:(1) 2012

14- Broadhurst PL: Determinants of emotionality in the rat. I. Situational factors. Br J Psychol 48(1):1-12, 1957

15- Castagné V, Moser P, Roux S, Porsolt RD. Rodent models of depression: forced swim and tail suspension behavioral despair tests in rats and mice. Curr Protoc Neurosci.; Chapter 8.ns0810as55, 2011

16- Conde CA, Costa V, Tomaz C:Measuring emotional memory in the elevated $\mathrm{T}$-maze using a training-to-criterion procedure. Pharmacol Biochem Behav 63(1):63-69,1999

17- Zatroch KK, Knight CG, Reimer JN, Pang DS: Refinement of intraperitoneal injection of sodium pentobarbital for euthanasia in laboratory rats (Rattus norvegicus). BMC Vet Res, 21;13(1):60, 2017

18- Magnotti RA Jr, Eberly JP, Quarm DE, McConnell RS:Measurement of acetylcholinesterase in erythrocytes in the field. Clin Chem 33(10):1731-1735, 1987. 
19- Rotruck JT, Pope AL, Ganther HE, Swanson AB, Hafeman DG, Hoekstra WG: Selenium: biochemical role as a component of glutathione peroxidase. Science179(4073):588-590, 1973.

20- Ohkawa H, Ohishi N, Yagi K : Assay for lipid peroxides in animal tissues by thiobarbituric acid reaction. Anal Biochem 95(2):351-358, 1979

21- Shah J, Gurbani S: Association of Vitamin D Deficiency and Mood Disorders: A Systematic Review.In Vitamin D Deficiency. Intech Open 27 1-16, 2019

22- Miu AC, Benga O:Aluminum and Alzheimer's disease: a new look. J Alzheimers Dis 10(2-3):179-201, 2006

23- Taïr K, Kharoubi O,Taïr $\mathbf{O A}$, et al: Aluminium-induced acute neurotoxicity in rats: Treatment with aqueous extract of Arthrophytum (Hammada scoparia).Journal of Acute Disease, 5(6), 470-82, 2016.

24- Svartz G, Aronzon C, Pérez Catán S, Soloneski S, Pérez Coll C. Oxidative stress and genotoxicity in Rhinella arenarum (Anura: Bufonidae) tadpoles after acute exposure to $\mathrm{Ni}-\mathrm{Al}$ nanoceramics. Environ Toxicol Pharmacol 80:103508. 2020.

25- Medhat E, Rashed L, Abdelgwad M, Aboulhoda BE, Khalifa MM, El-Din SS:Exercise enhances the effectiveness of vitamin D therapy in rats with Alzheimer's disease: emphasis on oxidative stress and inflammation. Metab Brain Dis 35(1):111120,2020 .

26- Zhang XJ, Greenberg DS:Acetylcholinesterase involvement in apoptosis. Front Mol Neurosci 5:40,2012.

27- Colomina MT, Roig JL, Sánchez DJ, Domingo JL:Influence of age on aluminum- induced neurobehavioral effects and morphological changes in rat brain. Neurotoxicology 23(6):775-781, 2002

28- Berihu BA , Afwerk M, Debeb YG, Gebreslassie A: Review on histological and functional effect of aluminium chloride on cerebral cortex of the brain. Internatinal $\mathrm{J}$ Pharm Scince Reservoir 6 (8), 1105:1116, 2015.

29- Shaw CA, Seneff S, Kette SD, Tomljenovic L, Oller JW Jr, Davidson RM:Aluminuminduced entropy in biological systems: implications for neurological disease. $J$ Toxicol 2014:491316. 201.2014.

30- Cordeiro JM, Silva VS, Oliveira CR, Gonçalves PP:Aluminium-induced impairment of $\mathrm{Ca} 2+$ modulatory action on GABA transport in brain cortex nerve terminals. J Inorg Biochem 97(1):132142.2003.

31- Ghita I, Zugravu A, Handra C, Segarceanu A, Negutu M, Fulga I: Experimental research concerning the effect of aluminium compounds on anxiety in mice.Farmacla 63(4): 568-73, 2015.

32- Kim S, Nam J, Kim K:Aluminum exposure decreases dopamine D1 and D2 receptor expression in mouse brain. Hum Exp Toxicol 26(9):741-746, 2007.

33- Kumar S: Aluminium-induced changes in the rat brain serotonin system. Food Chem Toxicol 40(12):1875-1880, 2002.

34- Munoz DG, Feldman H:Causes of Alzheimer's disease. CMAJ 162(1):65-72, 2000

35- Kesby JP, Cui X, O'Loan J, McGrath JJ, Burne TH, Eyles DW: Developmental vitamin D deficiency alters dopaminemediated behaviors and dopamine transporter 
function in adult female rats. Psychopharmacology (Berl)208(1):159168, 2010.

36- Eyles DW, Smith S, Kinobe R, Hewison M, McGrath JJ. Distribution of the vitamin D receptor and 1 alpha-hydroxylase in human brain. J Chem Neuroanat 29(1):21-30, 2005.

37- Katunar MR, Saez T, Brusco A, Antonelli MC: Ontogenetic expression of dopaminerelated transcription factors and tyrosine hydroxylase in prenatally stressed rats. Neurotox Res 18(1):69-81, 2010.

38- Cui X, Pertile R, Liu P, Eyles DW: Vitamin D regulates tyrosine hydroxylase expression: $\mathrm{N}$-cadherin a possible mediator. Neuroscience 304:90-100. 2015.

39- Orme RP, Middleditch C, Waite L, Fricker RA:The Role of Vitamin $\mathrm{D}_{3}$ in the Development and Neuroprotection of Midbrain Dopamine Neurons. Vitam Horm 100:273-297, 2016.

40- Mahar I, Bambico FR, Mechawar N, Nobrega JN:Stress, serotonin, and hippocampal neurogenesis in relation to depression and antidepressant effects. Neurosci Biobehav Rev 38:173$192,2014$.

41- Latimer CS, Brewer LD, Searcy JL, et al:Vitamin D prevents cognitive decline and enhances hippocampal synaptic function in aging rats. Proc Natl Acad Sci $U$ S A 111(41):E4359-E4366, 2014.

42- Taghizadeh M, Talaei SA, Salami M:Vitamin D deficiency impairs spatial learning in adult rats. Iran Biomed $J$ 17(1):4248,2013.

43- Kang H, Schuman EM : Intracellular $\mathrm{Ca}(2+)$ signaling is required for neurotrophin-induced potentiation in the adult rat hippocampus. Neurosci Lett 282(3):141-144, 2000.

44- Li L, Prabhakaran K, Zhang $\mathbf{X}$, et al:1Alpha,25-dihydroxyvitamin D3 attenuates cyanide-induced neurotoxicity by inhibiting uncoupling protein-2 up-regulation. $J$ Neurosci Res 86(6):1397-1408,2008.

45- Lee JS, Yang CS, Shin DM, Yuk JM, Son JW, Jo EK :Nitric oxide synthesis is modulated by 1, 25-dihydroxyvitamin D3 and interferon- $\gamma$ in human macrophages after mycobacterial infection. Immune Network, 9 (5): 192-202,2009.

46- Wang JY, Wu JN, Cherng TL, et al:Vitamin D(3) attenuates 6-hydroxydopamine-induced neurotoxicity in rats. Brain Res 904(1):67-75, 2001.

47- Buell JS, Dawson-Hughes B: Vitamin D and neurocognitive dysfunction: preventing "D"ecline?. Mol Aspects Med 29(6):415 422,2008.

48- Wang Y, Chiang YH, Su TP, Hayashi T, Morales M, Hoffer BJ, Lin SZ:Vitamin D(3) attenuates cortical infarction induced by middle cerebral arterial ligation in rats. Neuropharmacology 3;39(5):873-80, 2000.

49- Siegel GJ, Chauhan NB:Neurotrophic factors in Alzheimer's and Parkinson's disease brain:Brain Res Brain Res Rev 33(2-3):199227,2000 .

50- Nedzvetsky VS, Tuzcu M, Yasar A, Tikhomirov AA, Baydas G: Effects of vitamin $\mathrm{E}$ against aluminum neurotoxicity in rats. Biochemistry (Mosc) 71(3):239-244, 2006

51- Manal S, Azza H, EmanT : The Protective Effect of Vitamin E against the neurotoxic Effect of Aluminum Cholorid in Male Albino Rat. J Amer Sci, 6(10): 978-91,2010. 
52- Yang YX, Niu Q, Niu PY, Lou J. [Effects of aluminum on lipid peroxidation in rat's brain and its sex - related difference]. Zhonghua Lao Dong Wei Sheng Zhi Ye Bing Za Zhi 24(5):281-3. Chinese, 2006.

53- Newairy AS, Salama AF, Hussien HM, Yousef MI. Propolis alleviates aluminiuminduced lipid peroxidation and biochemical parameters in male rats. Food Chem Toxicol 47(6):1093-8,2009.

54- Kaizer RR, Corrêa MC, Spanevello RM, et al : Acetylcholinesterase activation and enhanced lipid peroxidation after long-term exposure to low levels of aluminum on different mouse brain regions. J Inorg Biochem 99(9):1865-1870,2005.

55- Lima LAR, Lopes MJP, Costa RO, et al :Vitamin D protects dopaminergic neurons against neuroinflammation and oxidative stress in hemiparkinsonian rats. J Neuroinflammation 15(1):249,2018.

56- Tohari AM, Zhou X, Shu X:Protection against oxidative stress by vitamin $\mathrm{D}$ in cone cells. Cell Biochem Funct 34(2):82-94, 2016.

57- Hajiluian G, Abbasalizad Farhangi M, Nameni G, Shahabi P, Megari-Abbasi M:Oxidative stress-induced cognitive impairment in obesity can be reversed by vitamin $\mathrm{D}$ administration in rats. Nutr Neurosci 21(10):744-752,2018.

58- Johnson WM, Wilson-Delfosse AL, Mieyal JJ: Dysregulation of glutathione homeostasis in neurodegenerative diseases. Nutrients 4(10):1399-1440,2012.

59- Gu F, Chauhan V, Chauhan A:Glutathione redox imbalance in brain disorders. Curr Opin Clin Nutr Metab Care 18(1):89-95,2015. 